\title{
KEY DRIVERS FOR GREEN BUILDING PROJECT FINANCING IN GHANA
}

\begin{abstract}
Purpose - The majority of the literature on green buildings in Ghana focuses on environmental benefits, innovative designs, construction technologies, and project management techniques. However, little is known about how such facilities are financed. This issue creates potential knowledge gaps, one of which this study aims to address. This study examines the key drivers for green building project financing in Ghana.
\end{abstract}

Design/methodology/approach - The study uses an explanatory sequential design with an initial quantitative instrument phase, followed by a qualitative data collection phase. An extensive critical comparative review of the literature resulted in the identification of eight potential drivers. One hundred and twenty-seven questionnaire responses based upon these drivers from the Ghanaian construction industry were received. Data was coded with SPSS v22, analysed descriptively (mean, standard deviation, and standard error), and via inferential analysis (One Way ANOVA and OneSample T-Test). This data was then validated through semi-structured interviews with ten industry professionals within the Ghana Green Building Council. Data obtained from the semi-structured validation interviews were analysed through the side-by-side comparison of the qualitative data with the quantitative data.

Findings - Though all eight drivers are important, the five key drivers for the Ghanian construction industry were identified as, in order of importance, 'high return on investment', 'emerging business opportunity', 'ethical investment', 'conservation of resources', and 'mandatory regulations, standards, and policies'. The interviewees agreed to and confirmed the importance of these identified drivers for green building project financing from validating the survey's key findings.

Research limitations/implications - Key limitations of this study are the restrictions regarding the geographical location of the collected data (i.e., Kumasi and Accra); timing of the study and sample size (i.e., the Covid-19 pandemic making it difficult to obtain adequate data) and the analytical tool used for the data analysis (i.e. the inability of the adopted tool to establish the relationship between some of the key drivers identified).

Practical implications - Though this study was conducted in Ghana, its implications could be useful to researchers, policymakers, stakeholders, and practitioners in wider Sub-Saharan Africa. For instance, financial institutions can invest in green buildings to expand their green construction and mortgage finance products to build higher value and lower risk portfolios. The findings from this study can provide investors with the enhanced certainty needed to help guide and inform their investment decisions, i.e., what to invest in, and when, by how much and how a scheme being 'green' may influence their rate of return. Also, for building developers, it will give them a clearer understanding of the business case for green buildings and how to differentiate themselves in the market to grow their businesses.

Originality/value - This study's findings provide insights into an under-investigated topic in Ghana and offer new and additional information and insights to the current state-of-the-art on the factors that drive green building project financing.

Keywords: Sustainability, Sustainable or green construction, Green buildings, Drivers, Green project financing, Ghana.

\section{INTRODUCTION}


Sustainability as a global phenomenon has led to the advocacy of sustainable development, which meets the present necessities without depriving future generations of the chance to meet their own needs (Opoku et al., 2019; Kates et al., 2005). As one of the world's largest industries, significantly contributing to countries' gross domestic products (GDPs), construction is also a significant user of energy, water, and raw materials (Akadiri et al., 2012). According to Shan et al. (2017), about $40 \%$ of the energy produced globally and between $40-50 \%$ of the world's raw materials are consumed by the construction industry. The processes associated with construction activities most often lead to environmental degradation and the depletion of non-renewable environmental resources (Masia et al., 2020). With its overdependency on natural resources from the earth, and with a lot of materials (in the form of solids, liquids, and gas) being returned to the environment as harmful, the construction industry has a significant impact on the environment (Masia et al., 2020). With the growing public consciousness of environmental damage that results from construction activities, the construction sector has now realised the need to seek solutions that are more environmentally harmonious (Masia et al., 2020). One such solutions as identified and accepted by the construction industry is adopting more green building practices and techniques. The Building and Construction Authority, BCA, (2014), defines a green building as an energy and water-efficient building that possesses a healthy indoor environment formed from eco-friendly materials.

The International Finance Corporation, IFC (2019) reports that venturing into green or sustainable buildings has been identified as one of the next decade's most significant investment opportunities. Shan et al. (2017) defines sustainable or green construction project financing to include raising financial capital for sustainable construction projects or sustainable development. According to Agyekum et al. (2020), green building project financing is any financial investment to develop and produce green or sustainable buildings. By the year 2030, the world is expected to witness a rise in green buildings with an estimated worth of $\$ 24.7$ trillion across emerging market cities (Verma, 2019). With high population growth and rapid urbanisation worldwide, cities in emerging markets are gradually (but at a fast pace) adopting green construction technologies to contain the problems that may arise because of this growth. In the view of Darko et al. (2018), these green construction technologies have the potential to combat the low-carbon economic growth and create skilled jobs in emerging markets for decades to come. A strong business case has been developed for growing the green building market. The benefits of green buildings provide investors and financiers platforms to shape and accelerate this multi-trillion-dollar business opportunity. For instance, emerging evidence suggests that green buildings are a higher value, lower risk asset than standard structures and have good cost savings of up to $21 \%$ (Dwaikat and Ali, 2016). The World Green Building Council (WGBC) (2013) further indicated that green buildings could decrease operational costs by up to $37 \%$. Also, Fuerst and McAllister (2011) were of the view that with green buildings, higher sale premiums of up to $31 \%$ and faster sale times could be achieved. Following this revelation, the WGBC (2013) iterated that such buildings have up to $23 \%$ higher occupancy rates, with a whopping rental income of up to $8 \%$. These benefits associated with green buildings provide investors and financiers platforms to lead in shaping and accelerating this multi-trillion-dollar business opportunity.

Despite the many benefits of green buildings worldwide, private and public developers find it challenging to fund such projects (Hupp, 2010). In a worldwide sustainability market survey carried out in 2019, it was revealed that people have a general perception that sustainability measures increase a given project's cost (Ramboll, 2019). Despite having ambiguous targets for green buildings, emerging markets are unable to come out with effective measures to mandate and incentivise the large-scale adoption of green construction practices (Chan et al., 2018 ). This notwithstanding, it is reported that the voluntary commitment from private sector actors across the value chain has contributed much to the development of the green buildings market through various forms of financing (The Guardian, 2012).

Like many developed and developing countries, the Ghanaian construction industry has now appreciated the need to contribute its effort to achieve the sustainable development agenda by adopting green building practices. However, Ghana's green or sustainable movement is still in its 
infancy (Agyekum et al., 2020; Agyekum et al., 2019). Though there have been efforts to certify several buildings springing up in Ghana, most sustainable projects are still at their initial stages. According to Addy et al. (2020), this problem is attributed to some key impediments to developing Ghana's green building market. Among the many obstacles identified by Addy et al. (2020), lack of fiscal incentives, which was explained as the industry not having any form of incentive (e.g., financial) to encourage stakeholders to participate in green building construction, was vital. Notwithstanding this flaw, the good news is that green buildings' full investment potential is within reach because of the presence of well-established financing models and proven easy-to-implement technologies that are readily available (Shan et al., 2017).

Currently, in Ghana, literature is available on green or sustainable buildings, with the majority concentrating on environmental benefits, innovative designs, construction technologies, and project management techniques ( Agyekum et al., 2019; Opoku et al., 2019). A critical area that is neglected, however, is the financing of green building projects. The IFC (2018) reported that SubSaharan Africa's cities, which Ghana is part, are home to more than 470 million people, with the number expected to double over the next 25 years. Hence meeting this housing need presents a significant opportunity for greening this future construction worth about $\$ 768$ billion until 2030 (IFC, 2019). When pushing for the adoption of more sustainable building projects, it is critical to discuss financing, especially the potential financial drivers or enablers and obstacles. Recently, Agyekum et al. (2020) examined the critical challenges to green building project financing in Ghana.

Notwithstanding this progress, very little is known about the drivers behind green building project financing, especially in Ghana, and hence is the aim of this research. Identifying the drivers is vital as it identifies critical enablers that can promote green building project financing. The key drivers will be determined via literature and then ranked via a questionnaire with contractors, consultants, and developers in the Ghanian construction industry. The survey's identified drivers will then be validated with key professionals in the Ghana Green Building Council. The findings are expected to benefit various stakeholders (e.g., financial institutions, investors, developers, policy makers, etc.) by enhancing their knowledge and skills in their search for more innovative ways of financing green building projects.

This study is organised into five sections. It begins with an introduction, followed by a critical comparative review of related literature. The literature review emphasises key issues such as financing sustainable or green building projects and drivers of sustainable/green building project financing. After this review, the methodology used to carry out the work is presented. This is followed by a presentation and discussion of the results, and finally, the conclusions and implications of the study.

\section{LITERATURE REVIEW}

The literature review is centred around sustainable or green construction, focusing on defining financing (with emphasis on some financial vehicles) and drivers of/for. Some models for green building project financing have also been briefly discussed. These subsections within the literature provide a theoretical basis on which the study is positioned.

\subsection{Defining sustainable or green building project financing}

Building users are more concerned with their buildings' efficiency, reliability, and affordability (Weerasinghe and Ramachandra, 2018). Sustainable or green constructed projects cost $1-25 \%$ higher than conventional buildings due to the introduction of materials and new technologies implemented in such buildings (Weerasinghe and Ramachandra, 2018). Notwithstanding, Lee et al. (2013) noted a 
paradigm shift from traditional buildings to sustainable construction projects to reduce the environment's damage (Dania, 2017). As part of the transformation needed, the concept of sustainable regeneration has received serious attention worldwide (Akotia and Sackey, 2018). Though important, the development and delivery of sustainable regeneration projects have proven to be a serious challenge for government agencies, industry practitioners, and communities in which such regeneration projects are situated (Akotia and Sackey, 2018). Despite this paradigm shift in recent years, there is still the question of how sustainable or green projects could be supported to increase propagation and market transformation. Shan et al. (2017) suggested a need to identify sustainable ways to finance these projects.

Sustainable or green construction project financing has been defined differently by various researchers. Shan et al. (2017) defined sustainable construction project financing to include raising financial capital for sustainable construction projects or sustainable development. In the view of Höhne et al. (2012), sustainable construction project financing is a financial investment geared towards sustainable construction projects. Soundarrajan and Vivek (2016) noted that sustainable project financing is a strategic method where several financial institutions like banks, insurance firms, property companies, mutual funds, institutional investors, and others direct their financial resources to sustainable development projects. The idea for financing sustainable construction projects significantly increased after the 2016 Group Twenty (G20) Summit where the Action Plan on the 2030 Agenda for Sustainable Development was released (Chakravarthi and Aravindan, 2019).

\subsection{Issues concerning green building project financing: the global, regional and Ghanaian contexts}

Finance has been identified as a critical barrier to adopting green building designs and technologies (United Nations (UN)-Habitat, 2018). Though this problem is encountered worldwide, it is more prevalent at the regional levels in Africa, where there are inadequate financial mechanisms for green building delivery (UN-Habitat, 2018). To achieve the internationally agreed targets of the Paris Climate Accord and Sustainable development goals, there is the need to mobilise financial resources privately and publicly (United Nations Environment Programme, UNEP, 2016). The World Investment Report (2014) estimates the global financial market for implementing the sustainable development goals (SDGs) through 2030 to be around \$ US 5 trillion.

Globally, several efforts in the form of policies have been put in place to promote green buildings' investments. Countries like the United Kingdom (UK), United States (US), Singapore, and Australia have all contributed their quota to educating and encouraging the masses to invest in green buildings (Shan et al., 2017). There have also been several efforts and initiatives from international organisations like the United Nations (UN), the Organisation for Economic Co-operation and Development (OECD), and the International Finance Corporation aimed at encouraging investment in green buildings (Shan et al., 2017; OECD, 2015). Within the UK, the policies and practices guiding green building project financing come in direct subsidy and create institutions and mechanisms to catalyse investment into green projects (Halper, 2015). In the USA, Tobias et al. (2017) indicated that the government had provided several financing options at various levels, such as the federal, state, and municipal, to help develop green buildings. Singapore saw a rise in green buildings from 17 in 2005 to over 2100 in 2014 (Hwang et al., 2018). This development is attributed to about ten financing programmes instituted by the Singapore government (Hwang et al., 2018). Such financing programmes are reported to include Building Retrofit Energy Efficiency Financing, Green Mark Incentive Scheme for Existing Buildings, Green Mark Gross Floor Area Incentive Scheme, among others (Shan et al., 2017). Australia has also seen the Federal government establishing a Green Building Fund that amounts to $\$ 71.24$ million to fund green retrofit to existing buildings (Green 
Building Council Australia, 2008). The efforts and initiatives from international organisations towards green building project financing are also well reported in the literature (OECD, 2015).

Though in Africa not much is known regarding green building project financing, there have been a good number of reports in portions of East Africa, South Africa and West Africa. In East Africa, the potential increase in building stock in decades to come makes green design practices and construction critical (UN-Habitat, 2018). Unfortunately, unlike in other developed countries where financial institutions are being shaped into financing more sustainable buildings, that cannot be said concerning such institutions in East Africa (UN-Habitat, 2018). This problem is attributed to the characteristics of the East African property finance Market (e.g. high-interest rates/cost of debt and low liquidity from shallow capital markets), making it difficult for such investments to be made. In South Africa, Bhandari (2014) reports the South African green fund that was established in 2011. According to Bhandari (2014), the fund provides grant and loan finance to public and private actors supporting South Africa's various green initiatives and national plans. Though this initiative has been in existence since 2011, Bhandari (2014) reports that it faces limitations, key amongst which are limited financial resources, complex diligence and application requirements, inadequate understanding of the dynamics of various projects, and broad focal areas of the fund.

Though Ghana is still young in the green building movement, recent years have seen an increase in the number of publications that create awareness of green buildings' various aspects. A good number of studies have been dedicated to examining the drivers (Agyekum et al., 2020), barriers (Agyekum et al., 2019), and strategies to promote green buildings (Darko et al., 2018). Other studies have also been dedicated to developing frameworks for green building certification (Ampratwum et al., 2019) and technologies adoption (Darko, 2019). Currently, the issue of the green economy has been identified by Ghana as an important vehicle that can help achieve sustainable development of the country. Therefore, this has sparked the introduction of some initiatives to reform national fiscal policies for green finance (Partnership for Action on Green Economic (PAGE), 2015). In a report by PAGE (2015), there are significant green finance opportunities for the Ghanaian business community across sectors like energy, agriculture, transport, waste and industrial. Though these opportunities in the various sectors were well reported by PAGE (2015), little was said regarding green financing opportunities for the building construction sector. A study conducted by Agyekum et al. (2020) reveals that the building construction sector encounters some obstacles when it comes to green building project financing. The key blocks were identified to include split incentives, risk-related barriers, capital expenditure, lack of incentives and initial capital cost. Notwithstanding, certain financial vehicles are available for green building project financing, which the Ghanaian construction industry can explore.

\subsection{Financial vehicles for green building project financing}

Financial vehicles are investment tools used to finance projects and include government interventions, green bonds, bank loans, international assistance, and private funding. 


\subsubsection{Government intervention}

Financing sustainable or green building projects require enormous financial investment (Zhan and de Jong, 2018). There is a high risk attached to such projects; the government must play a pivotal role in driving the agenda (Lee et al., 2013). The US government at the federal, state, and local levels plays an essential role in promoting sustainable construction of projects and financing such projects to ensure that their buildings meet sustainable requirements (Tobias and Llc, 2007). Vardhan (2017) indicated that governments in most developing countries attract foreign investment by granting tax incentives. According to Chakravarthi and Aravindan (2019), lack of incentives is one of the critical factors that affect sustainable construction projects' endorsement. In Malaysia, for instance, building projects that meet the green building index are given property tax reduction. Depending on the level of certification of the property, the building owner may get a tax credit (Lockwood, 2008). Diyana and Abidin (2013) further indicated that the Malaysian government had introduced the Green Technology Financing Scheme to accelerate the construction and retrofitting of more buildings to meet sustainable certifications. Thornley et al. (2011) suggested that the supports that governments provide are basically in the form of tax incentives given through tax reductions or exemptions on materials and equipment used in the construction of sustainable projects. There could also be tax credits in the form of cash backs given to investors who financed such projects (Thornley et al., 2011).

\subsubsection{Green bonds}

A green bond is a debt instrument that offers a fixed return and promises to use the profits to finance, in part or wholly, new or existing sustainable projects (Ernest and Young (EY), 2015). Chakravarthi and Aravindan (2019) defined green bonds to mean a debt instrument specially earmarked to be used for financing climate and environmentally friendly projects. The bond is usually issued by financial institutions, governments, or firms that need to raise funds from the capital market for a specific time (Salman et al., 2016). It can also be defined as an income tool that allows the issuer to tap into debt capital markets and use the proceeds to finance projects with environmental benefits (OECD, 2012). They are like conventional bonds in almost all facets apart from the use of profits that their issuer allocates for investments in sustainable projects, an intention that is commonly specified in the bond's legal terms. OECD (2015) argued that the use of green bonds could be differentiated from the other bonds by how the proceeds are utilized, which signifies a commitment to entirely use the funds raised to finance or re-finance sustainable projects, assets, or business activities.

\subsubsection{Bank loans}

Banks play a crucial part in the financing of infrastructure around the world. They are the primary source for financing any needs. They can choose to lend to a clean or dirty industry. In recent years regulations concerning sustainability have been introduced by members of the Sustainable Banking Network hosted by the International Finance Corporation, which aims to allow the banks to invest in more sustainable construction projects (Cui et al., 2018). Banks are active in investments in sustainable construction projects by providing funds for entities that are playing a crucial role in sustainable development (Jeucken, 2001). One of the most common financing vehicles used for financing infrastructure is bank loans since they are flexible and easy to obtain. According to Zhan and de Jong (2018), Tianjin Eco-City Investment and Development (TEID) Company Limited, the financiers of the Sino-Singapore Tianjin Eco-City (SSTEC) project, collaborated with 12 different banks and raised (Chinese Yuan) CNY 10.24 billion to finance their project. In America, banks such as Citicorp, Bank of America, and Wells Fargo have announced significant green lending plans (Tobias and Llc, 2007). The Romania Green Building Council (RoGBC) has partnered with banks to provide a mortgage to prospective customers who want to purchase sustainable buildings (RoGBC, 2014). Local banks in India such as the State Bank of India, the Industrial Development Bank of India 
(IDBI Bank), and the Industrial Credit and Investment Corporation (ICICI) Bank, as well as foreign banks including Standard Chartered, Barclays, and the Algemene Bank Nederland-Amsterdam Roterdam (ABN AMRO) Bank operating in the country, have launched financial vehicles that are aimed at financing renewable energy projects (Soundarrajan and Vivek, 2016).

\subsubsection{International assistance}

According to the Organisation for Economic Co-operation and Development, OECD (2014), International Finance Institutions (IFIs) provide funds for sustainable or green construction projects in Eastern Europe. Funding for such projects can be secured from various international organizations or groups interested in sustainable projects to protect the environment. Measures have been put in place by the OECD to support nations to scale up public finance and attract private investment for sustainable construction projects (OECD, 2012). From 2005, IFC, a World Bank Group, had invested $\$ 15$ Billion in sustainable or green construction projects and aimed at increasing investment in such projects by $28 \%$ in the year 2020 (IFC, 2017). Kapoor (2012) revealed that the IFC group provides financing for sustainable or green construction projects and provides upstream investment in technology and materials used in the construction of such projects, thereby reducing the cost of this technology and materials to the end-users.

\subsubsection{Private funding}

Sustainable or green construction projects involve long-standing and permanent investments (Chan et al., 2009). Conventionally, public funds are a critical financial source for sustainable projects. However, given the pressure on public resources, private funding is crucial and needed to finance such projects (Love et al., 2015). For instance, Zhan and de Jong (2018) indicated that part of the funds used for constructing the Sino-Singapore Tianjin Eco-City was privately sourced to reduce the pressure on governments and its local representative. Private funding can be obtained from insurance companies, charities, pension funds, mutual and endowment funds. Yudelson (2010) indicated a massive growth in the amount of private funding from private firms used in the sustainable construction sector. Transitioning to a more sustainable development era over the next 20 years requires significant investment from private sources and on a much larger scale than previously. Meltzer (2015) noted that about $\$ 3$ trillion per annum is needed to fund sustainable or green construction projects over the next 15 years. To attain this threshold, the private sector is required to mobilize half of this amount to help fund such projects. Merk et al. (2012) postulated that the private sector could fill the gap for investment in sustainable construction projects by engaging them through public-private partnerships (PPPs) or private finance initiatives to scale the level of investment in sustainable construction projects. Bielenberg et al. (2016) supported this assertion and iterated that involving the private sector in financing sustainable projects can bring other benefits apart from the investment. According to Patil and Boeing (2016), PPPs are the preferred route for developing infrastructure projects by both developed and developing countries. For instance, India is among the countries which have actively pursued PPPs for infrastructure activities since 2006 (Patil and Laishram, 2016). Patil and Laishram (2016) further iterated that in both the Federal and State Governments, PPPs have been encouraged to make infrastructural developments attractive to private sectors.

\subsection{Drivers of sustainable or green building project financing}

An extensive critical comparative review of the literature was conducted, and potential drivers of sustainable or green building project financing were identified. For this review, drivers have been defined as the essential enablers that can help promote green building project financing. The subsections that follow discuss some important drivers identified in the literature in detail. 


\subsubsection{Corporate social responsibility (CSR)}

According to McWilliams and Siegel (2001), corporate social responsibility refers to actions that promote some social good beyond the firm's benefits and not mandated by law. Orlitzky et al. (2006) also defined corporate social responsibility to include decisions that enhance competitiveness and reputation. Such decisions should result in growth in the financial and economic performance of the entity. When global climate change issues have received massive attention, there is increased regulatory, consumer, and employee pressure for corporations to become energy efficient and reduce their carbon footprints (Sullivan and Gouldson, 2017). Franc et al. (2006) indicated that researchers' definitions of corporate social responsibility give credence to the European Commission's report that these collective actions improve society's wellbeing. These developments have driven CSR programs like the Carbon Disclosure Project and the Climate Registry (O'Mara and Bates, 2012). Previous studies report on CSR strategies' influence on consumer attitudes, employee performance, and cost structure (Nguyen, 2014). Unfortunately, not much is known regarding green buildings' importance as a CSR tool (Nguyen, 2014). CSR strategies provide the basis for establishing environmental management systems and developing the expertise to identify green investments opportunities (PAGE, 2015). For instance, in Ghana, many organisations invest in several socially responsible areas (PAGE, 2015); however, little is known about the Ghanaian construction sector. This issue needs to be addressed because Nguyen (2014) postulated that fixed assets are crucial, especially considering the huge investments.

\subsubsection{Ethical investment}

Ethical investment, also known as sustainable investment, responsible investment, or values-based investment, involves incorporating environmental, social, and governance factors when making investment decisions rather than purely relying on financial considerations (Global Sustainable Investment Alliance, GSIA, 2019). Green buildings have been identified as the epicenter of responsible investment (Day, 2019). Ethical investment has been an emerging trend in the financial services industry. Investors, financing banks, and specific commercial buildings users are now subject to environmental, social and governance reporting obligations. Therefore, these obligations have invested in green buildings, a hot topic among these stakeholders (Day, 2019). The financial sector has always been the priority investor when it comes to responsible investment. For instance, in the United States, about $13 \%$ of the total investment made by financial institutions is geared towards ethical investment funds (Michelson et al., 2004). Such funds are reported to finance sustainable or green construction projects because it helps save the environment (Michelson et al., 2004).

More recently, the European Commission announced in its Action Plan to explore a potential recalibration of capital requirements for banks concerning investments in green buildings (Day, 2019). Following this action plan, the European Union has set in motion several initiatives to find solutions to enable banks to invest in the green building sector (Day, 2019). A report by the GSIA (2019) revealed that globally, sustainable investing assets in the five key markets (Europe, United States, Japan, Canada, Australia/New Zealand) stood at $\$ 30.7$ trillion at the start of 2018. This figure is reported to be a $34 \%$ increase in two years. In Europe alone, total assets committed to responsible investment strategies (including investment in green buildings) grew by 11\% from 2016 to 2018, reaching \$14.1 trillion (GSIA, 2019). These figures are not surprising because most of these critical markets dominate green buildings. In Africa, the $5^{\text {th }}$ Edition of the Bertha Centre for Social Innovation and Entrepreneurship's African Investing for Impact Barometer revealed that ethical investments continue to grow with $\$ 428.3$ billion in assets as of July 31, 2017 (GSIA, 2019). Unfortunately, when it comes to green building developments, Africa is far behind. It is therefore unclear if such investments are diverted to other sectors instead of the green building sector. 


\subsubsection{Corporate image}

Enshassi and Mayer (2005) defined a corporate image as the perception of an entity in the stakeholders' eyes involved with the entity. According to Ross (2015), issues of sustainable development have reached critical levels in recent times. Thus, they have made lots of companies around the world adjust their corporate images and showcase their environmental integrity by buying into the idea of issuing or investing in green bonds. Ko et al. (2013) postulated that green/eco-friendly activities are identified as effective tools that underpin corporate image since those activities portray the firm's positive image and show the organisation's effort towards society. Klein and Dawar (2004) reported that an organisation's environmental performance and records are considered a vital CSR construct. Organisations that invest their efforts in environmental issues can represent a better image than those that do not (Chen, 2008). To place this in a better context, Chen et al. (2006) suggested that organisations can improve their corporate image through green innovation (i.e., investing in ecofriendly activities like green buildings). In the view of Darko et al. (2017), this factor is a critical driver for implementing green building technologies worldwide. Agyekum et al. (2020) also identified this factor as an essential driver of green building certifications in Ghana. In confirmation of that postulated by Ross (2015), the Ernest and Young (EY) group indicated that one of the significant drivers of issuance of green bonds by companies is to enhance their brand as an environmentally conscious organisation (EY, 2015). Della Croce et al. (2011) noted that investors improve their reputation by showing concern for the environment by investing in sustainable construction projects. Inderst et al. (2012) reported that one of the motivators for financing sustainable construction by an investor or company is to improve its reputation and market itself.

\subsubsection{Emerging business opportunity}

According to Lotfi et al. (2018), environmental concerns raised over the years and awareness created for consumers to buy or use green products have brought about several business opportunities in various fields. The construction industry is one of them. The International Finance Cooperation is one of such investors taking advantage of the emerging business opportunities by investing in sustainable or green projects. The investment is in companies that manufacture sustainable building materials (IFC, 2010). Investors are taking advantage of the incentives such as tax grants and other financial and regulatory incentives provided by governments to diversify into sustainable construction projects to maximise profits (Yudelson, 2010). Several studies have shown how stakeholders are taking advantage of the incentives to invest in sustainable construction projects (Mathews, 2012; Gündoğan, 2012).

\subsubsection{Other drivers for green building project financing}

Other equally important factors that drive green building project financing include reduced lifecycle cost of the projects, conservation of resources, high return on investment, and mandatory legislation and standards. These drivers are briefly discussed in the paragraphs below:

The reduced lifecycle cost of projects: The reduced lifecycle cost of projects is an appraisal tool used to evaluate various investments by considering the price and savings along a specific period (Dwaikat and Ali, 2014). It is basically to check the cost of owning a facility. The International Standard Organisation (ISO) 15686-5:2008 throws light on the details of a building's life cycle. It categorizes the life cycle cost of a building into four groups, namely (1) design and construction cost, (2) operational cost, (3) maintenance cost, and (4) end life of cost (Dwaikat and Ali, 2014). Fletcher (2009) indicated that apart from the environmental benefits of sustainable buildings, another benefit derived is the savings made due to the integration of water and energy-saving equipment which in turn reduces the life cycle cost of the project. Dwaikat and Ali (2014) noted that a growing body of 
literature suggests that sustainable or green buildings outperform conventional buildings in many areas and one area is the economic aspect that is assessed using life cycle costing as an appraisal tool.

Conservation of resources: Conservation of resources with emphasis on the environment is a complex driver. It incorporates both altruistic and egoistic motivations to prove a project's feasibility (Chmutina et al., 2014). Sustainable or green buildings incur contractors and buyer's extra cost due to sustainable building technologies and alternative materials to conserve resources. Still, the benefits of constructing sustainable buildings can far outweigh the cost of conventional buildings (Neyestani, 2017). The judicious use of resources during construction is vital to achieving sustainable buildings or construction (Kakkar, 2014). Akadiri et al. (2012) noted that the critical strategies for resource conservation are energy conservation, material conservation, water, and land conservation. Khosla and Singh (2014) also argued that sustainability advocacy had changed the way people build; the aim is to make the building more energy-efficient and less expensive to operate and maintain. One of the significant benefits of sustainable buildings widely reported in the literature is the energy savings made.

High return on investment: In Australia, Low et al. (2014) found that retrofitting an existing building or leasing a commercial building deemed sustainable brought a $10 \%$ return on interest compared to other commercial properties that were not sustainable. Azizi et al. (2011) noted that with the advent of the sustainable development drive across the world, developers sell commercial facilities with ecolabels faster, thereby encouraging them to invest in such properties. According to Andelin et al. (2015), developers and owners define a property's value as the market value of their property, which is determined by how attractive it is and the kind of facilities in the property. As noted by the World Green Building Council (WGBC) (2013), the rental and occupancy rate of property directly relates to its market value. An example is the Santiago Rising in Chile, a Leadership in Energy and Environmental Design (LEED)-certified building built at a lower cost than a similar conventional high-rise building and fully booked because of the environmental benefits and lower operating cost of the facility (WGBC, 2013). According to Turner (2010), sustainable buildings have high occupancy rates, which translate into higher asking rents, which gives investors in such facilities a more significant amount of return on their investment. Return on investment is as high as $52 \%$ compared to non-sustainable buildings (WGBC, 2013).

Mandatory legislation and standards: Most environmental regulatory instruments' basic idea is that most stakeholders would not undertake any environmentally beneficial projects without regulatory pressure from authorities (Chmutina et al., 2014). According to Alsanad (2015), one of the factors that have driven the Kuwait market for sustainable construction projects has been introducing legislation by the government to encourage more of such projects. Darko et al. (2018) noted that the construction industry raising standards regarding how construction is done was a way of driving interest in investors investing in the sector, knowing that their projects adhere to standard to conserve the environment. Land use regulations and urban planning policies were significant drivers used to increase participation in the Greek sustainable construction sector (Manoliadis et al., 2006). According to Azizi et al. (2011), the impact of international pressure on governments worldwide is making them put a premium on formulating legislation that moves the construction industry towards sustainability. In Hong Kong, one of the drivers used to promote financing and participation in sustainable construction projects is the implementation of regulations that encourage stakeholders in the construction industry to make environmental changes to their operations (Darko et al., 2018).

\subsection{Review of models for green building project financing}

Several innovative models for sustainable project financing exist in the literature. One of the several financing models developed is the Certified Emission Reduction (CER) model. In this model, governments guarantee the increased cost of green projects in return for CER which is the savings made from energy during the operational stage of the project (Lee et al., 2013). In their paper, Yamaguchi and Managi (2017) proposed the Green Net National Product (GNNP), where the aspect 
of green or environment was tied into the gross national product, which targets traditional economic indices. In this model, governments issued bonds will have their interests tied to the GNNP. Many notable financial institutions have also come up with innovative ways of financing green projects. Some of these models are bonds, green equity financing, trust funds project financing, carbon financing and emission trading (Asia-Pacific Economic Cooperation (APEC), 2018). The models and their terms vary depending on the implementing institution.

Other green building financing models include the Mizuho Environmental Private Bond, National Carbon Emission Trading by the National Development and Reform Commission (NDRC) of China, Green Living Equity Investment Fund developed by China, and the Aviation Industry Corporation (AVIC) trust created by China (APEC, 2018). Similar Green Business models that are identified in literature used for financing green projects are Incentive Models, which incentivizes consumers to ensure the entire value chain is green and the Life-cycle model which focuses on greening the value chain of companies (Eskelson et al., 2016). Punzi (2019) developed the environmental dynamic stochastic general equilibrium (E-DSGE) model. This model proposed green firms producing below low-carbon emissions to finance their investments and production only through banking loans. In contrast, non-green firms that produce high-carbon emissions needed permits from their government to allow their production. The latter firms can finance their investments either with bank loans or by issuing equities. Such a model can be replicated in the construction industry to finance green building projects. In an article for Energy Foundation, a list of green financing models were examined critically to know how best they can be used to finance green projects, including energy efficiency projects (Kats et al., 2011). Some of those models were identified as Carbon Market Funding, Property Assessed Clean Energy (Residential and Commercial ), Energy Savings Performance Contracting (ESPC) and Unsecured Consumer Loans (Kats et al., 2011). All these financing models have been developed to have adequate financing for green projects.

\subsection{METHODOLOGY}

A mixed-method approach (both quantitative and qualitative) was employed. This study adopted a design that uses qualitative data to explore the quantitative findings. This design is exploratory sequential and involves two phases, i.e., 1) an initial quantitative instrument phase (see sections 3.13.2) followed by 2) a qualitative data collection phase (see section 3.3). The paper settled on this design because after the literature review, there was sufficient information concerning the drivers (and financing) of green buildings. With this information, it became easier for the study to focus on the views of the respondents concerning that which is already available (quantitative survey) and following it up with their actual views concerning the subject under study (qualitative). This design is preferred when a study seeks to explain the quantitative results (in this case the key drivers identified) in more detail through the qualitative data obtained (Wisdom and Creswell, 2013). This design further helped establish how respondents' personal experiences regarding the key drivers matched the results obtained from the questionnaire survey. The methodology adopted is further presented in Figure 1, which shows the procedures used. The explanation to the flowchart is also provided in sub-sections 3.1-3.3.

\section{[INSERT FIGURE 1]}

\subsection{Design of questionnaire and survey administration}

The questionnaire was divided into two sections, the respondents' demographic information and respondents' assessment of the drivers for green building project financing. After designing the questionnaire, a two-step piloting procedure was used to access its appropriateness for the intended purpose. The piloting was important to ensure that valid data was collected. The first step was reviewed by an expert in green building developments (a senior academic with more than ten years of working experience) within a developing country. In the second part of the piloting, interviews were 
conducted with five industrialists from various backgrounds (i.e., Architects, Engineers, Contractors, Developers) who had experience in green buildings within the local context (Ghana). They were also requested to check the questions' suitability and determine if any drivers had been omitted. From the two-stage pilot study, all the respondents agreed with the list of drivers. They provided encouraging feedback which resulted in the questionnaire questions being made more explicit and less ambiguous.

Following the piloting, the instrument was finalised. In the first part of the questionnaire, the respondent's information gathered included: institution/organisation, position, qualification, years of working, and years involved in sustainable building projects. The second part required respondents to rate the extent to which they perceived the drivers drove the financing of green building projects using a five-point Likert scale $(1=$ Not important, $2=$ Less important, $3=$ Quite important, $4=$ Important and $5=$ Very important).

There are currently 12 green certified buildings in Ghana (Botchway, 2020). of these, seven have been completed, one abandoned, and the remaining four are under construction (Botchway, 2020). Accra (the capital city of Ghana) has five of the green buildings completed, four under construction and one abandoned (Botchway, 2020). Kumasi and Takoradi each have one completed green building (Botchway, 2020). However, geographically, this study was limited to key industry practitioners (building contractors, consultants, and developers) within Accra and Kumasi because these are the two largest cities in Ghana, and consequently have the greatest concentration of these professionals with knowledge and experience in green construction. The expertise of such practitioners was sought during developmental projects in other parts of Ghana. The questionnaire was distributed face-to-face to these key industry practitioners Respondents within the Building Contractors category were selected from Class D1 building construction firms. Those within the Consultants were chosen from the Institution of Engineering and Technology Ghana (IETG), Ghana Institute of Surveyors (GhIS), and the Ghana Institute of Architects. Respondents under the Developers category were property investors who operate under the umbrella of Ghana Real Estate Developers Association (GREDA).

Non-probability sampling approaches (i.e., purposive and snowball sampling approaches) were used to select the respondents. These approaches were used because there was no sampling frame from which the respondents could be selected. The respondents were hence selected based on their knowledge of the topic and their willingness to partake in the study. The purposive sampling technique was used to identify the respondents in the three groups with the required knowledge and experience. The snowball sampling technique is used to generate a pool of participants for a research study through referrals made by individuals who share a particular characteristic of research interest with the target population (Crouse and Lowe, 2018). In this study, the snowball sampling technique was used to recognise other respondents who also had knowledge and expertise by inquiring from the respondents selected earlier. Out of the 150 questionnaires distributed, 127 questionnaires (51 from Contractors, 43 from Consultants, and 33 from Developers) were returned (through in-person collection) completed, a very good response rate of approximately $85 \%$. The data collection spanned a period of 9 months, i.e., from November 2019 to August 2020. It took that long to obtain the data because of the COVID-19 Pandemic in 2020 that brought most businesses to a halt in Ghana. The respondents' profiles are summarised in Table 1.

\section{(INSERT TABLE 1)}

Out of the total number (127) returned, Architects constituted 32\%, Quantity Surveyors constituted $27 \%$, Site Engineers constituted 24\%, and Project Managers constituted 17\%. In terms of the respondents' educational backgrounds, $42 \%$ possessed master's degrees, $34 \%$ bachelor's degrees, $22 \%$ had Higher National Diploma degrees, and those with other certificates constituted $2 \%$. The working experience revealed most of the respondents $(80 \%)$ having between 5 to $25+$ years of experience. Twenty per cent $(20 \%)$ had less than five years of working experience. Most of the respondents $(90 \%)$ indicated that they had some sustainability experience ( 1 to $10+$ years). 
Concerning the types of companies, the respondents worked in, $40 \%$ were with building construction companies, $34 \%$ were with consultancy, and $26 \%$ were with developers (e.g., real estate companies).

\subsection{Analysis of quantitative data}

The questionnaire data were analysed with IBM SPSS v22. The analysis was both descriptive (i.e., mean, standard deviation, and standard error) and inferential (i.e., One-Way ANOVA and OneSample T-Test) in nature (Table 2). The Cronbach's Alpha Test was conducted to check the data's reliability by checking the scale's internal consistency for the rating of the various drivers. A score of 0.70 and above indicates the scale being used for the rating is internally consistent (Bonett and Wright, 2014). On conducting this test, a value of 0.713 was obtained, an indication that the Likert scale used to rate the drivers were reliable; hence, reliable data will be achieved. The drivers were ranked by their mean. The inferential analysis was employed to check if there was any significant difference amongst the means of the different groups of participants.

The One-Sample T-Test was conducted to check the various means of the drivers against a mean test value of 3.50. In this case, the null hypothesis $\left(\mathrm{H}_{0}\right)$ was defined to mean that the mean score was not statistically significant. The alternative hypothesis $\left(\mathrm{H}_{1}\right)$ was defined to suggest that the mean score was statistically significant. The one-sample T-Test was conducted at a $95 \%$ confidence level with a $p$-value of 0.05 . The null hypothesis was rejected where $p<0.05$ at a $95 \%$ confidence level while the alternative hypothesis $\left(\mathrm{H}_{1}\right)$ held where $p>0.05$ at a $95 \%$ confidence level. The hypothesised mean of 3.5 was used in this study because if per the Likert scale used, $5=$ very important, and $4=$ important, then for a variable to be consistently considered important, it must have a mean above the neutral point (i.e., 3). Therefore, the hypothesised mean for this value was set between 3 and 4 (in this case, 3.5). This test value, as settled on, signifies that the factors with a mean score of 3.5 and above were key drivers for green building project financing. Other green building related studies have also used this hypothesised mean of 3.5 (Agyekum et al., 2021; Agyekum et al., 2020). The One-Way ANOVA was further used to compare the means of the three different participant groups to determine if there was any statistically significant difference amongst the groups' means. Kendall's coefficient of concordance $\mathrm{W}$, a non-parametric test, was used to determine if there was an agreement in the rankings. The $\mathrm{W}$ ranged from 0 (indicating no agreement) to 1 (complete agreement) (Field, 2013). Though an important analytical tool, the One-Way ANOVA can only be used to investigate a single factor and a single dependent variable. It is more suitable when comparing the means of three or more groups (in this study, contractors, consultants, and developers). Although it can tell if one pair of means is significantly different, its key disadvantage is that it cannot tell which exact pair (Frost, 2020). A more robust analytical tool like Structural Equation Modelling (SEM) can be implored when this happens. The SEM can go beyond just identifying the factors to examining the relationship between such factors (Suhr, 2006).

\subsection{Design of interview guide, conducting interviews and analysing qualitative data}

This phase of the study was initiated following the results from the quantitative phase. The idea was to get interviewees to explain the quantitative results in more details through the qualitative data. An interview guide was prepared, which required the interviewees to provide information on how the identified drivers are important for green building project financing.

Ten (10) key respondents in the form of contractors, consultants, and developers in active service and who are part of the Ghana Green Building Council were interviewed to provide their views regarding the drivers under investigation. Many articles, book chapters, and books recommend guidance and offer anywhere from 5 to 50 participants as adequate in a qualitative study (Yin, 2014). Parse (1990) also suggested that for a qualitative study where researchers seek to obtain rich data, two to ten participants are recommended. This notwithstanding, depending on the context of the research being conducted, researchers can settle on any required number provided they are in the position to examine 
and assess all the views of the interviewees critically. Other sustainability related studies have used between 2 to 10 participants ( Opoku et al., 2019;). As a matter of fact, the ten respondents for the qualitative bit of this study were adequate to provide the information needed for this study. The interviews became necessary because the authors wanted to know what the experts think beyond identifying the various drivers. The interviews were also essential to further validate the findings of the quantitative data during the discussion. The interviewees were contacted by telephone because of their busy schedules.

Following the design adopted, data obtained from the semi-structured validation interviews were analysed through the side-by-side comparison of the qualitative data with the quantitative data.

\subsection{RESULTS AND DISCUSSION}

\subsection{Assessing drivers for green building project financing}

Table 2 summarises the survey results on the drivers for green building project financing in Ghana. The three respondent groups' views regarding the individual drivers showed different mean scores across the various indicators. The mean scores were used to rank the level of importance of the various drivers in descending order. If two or more drivers were found to have the same mean score in the ranking, the driver with the lowest standard deviation was ranked higher.

For the respondent group 'contractor', the results show that the importance of the drivers ranged from 3.82 to 4.71 , for 'consultant' 3.77 to 4.77 , and for 'developer' 3.73 to 4.67 (see column 3 of Table 2). The contractors ranked high return on investment $[\mathrm{MS}=4.71, \mathrm{SD}=0.502]$ as the most important driver for green building project financing, while corporate social responsibility $[\mathrm{MS}=3.82, \mathrm{SD}=$ 0.684 ] was ranked as the least. Similarly, the consultants ranked high return on investment $[\mathrm{MS}=$ $4.77, \mathrm{SD}=0.480]$ as the most important, with corporate social responsibility $[\mathrm{MS}=3.77, \mathrm{SD}=$ 0.649] ranked the least (see Column 4 of Table 2). For the developers, the emerging business opportunity $[\mathrm{MS}=4.70, \mathrm{SD}=0.637]$ was ranked as the most important driver for green building project financing, whereas corporate social responsibility $[\mathrm{MS}=3.73, \mathrm{SD}=0.626]$ was ranked the least (see column 5 of Table 2).

Following the assumption that a company type may influence respondents' perceived importance of the individual drivers, an analysis of variance (ANOVA) was further conducted to determine if there existed any significant differences in the respondents' views regarding the importance of the drivers. The mean scores among the respondent groups were considered significant, where $p<0.05$. The ANOVA results (Table 2) showed no significant differences between the respondents' views regarding the individual drivers. This means that for all the drivers, though there appeared to be some differences in the opinions of the respondent groups when the mean scores were compared, the differences were not significant, i.e., $p>0.05$. This further meant that the views of the respondents could be pooled together.

\section{[INSERT TABLE 2]}

When the data were collated together, it is evident that the overall mean values of the importance of the drivers range from 3.78 to 4.72 across all the participants (see column 2 of Table 2). This means that when the overall results were compared, the respondents ranked high return on investment $[\mathrm{MS}=$ $4.72, \mathrm{SD}=0.502]$ as the most important driver for green building project financing, whiles corporate social responsibility $[\mathrm{MS}=3.78, \mathrm{SD}=0.654]$ was ranked as the least. Also, all the remaining drivers recorded mean scores higher than 4.0, indicating the relative importance of all of them. Though all the drivers were ranked as important, those drivers with mean scores greater than 4.5 (i.e., 'very 
important' per the rating scale) were considered key and are, therefore, the focus of discussion. The five key drivers are therefore discussed to include the following:

High return on investment (DV7): This driver was the overall most important [MS $=4.72]$ and [SD $=0.502]$. Though there existed some mean difference between the consultants (CS) and developers (DP) $[\mathrm{MD}=0.10]$, and the contractors (CT) and developers (DP) $[\mathrm{MD}=0.04]$; the ANOVA result revealed however, that these differences were not statistically significant $(p=0.798>0.05]$ (see Table 2 ). From the combined results, the one-sample t-test revealed that this driver is statistically significant as the mean score is greater than the mean value of 3.5 and the $p$-value is less than $0.05(p=0.000<$ 0.05). This finding corroborates literature that reports on DV7 as a key enabler for financing green buildings (Andelin et al., 2015; Low et al., 2014; WGBC, 2013; Azizi et al., 2011; Turner, 2010). Like that found in this study, Andelin et al. (2015) revealed that high return on investment in Finland is an important factor that drives both investors and tenants into investing in green buildings. Similarly, in Singapore, Low et al. (2014) found this factor to be a major motivation to green new and existing buildings. Azizi et al. (2011) also believed that though in New Zealand investors are posed with risks associated with an investment in green buildings, the high returns to gain on their investment is a key factor that motivates them to invest in such buildings.

Commercial properties with eco-labels sell faster and command higher interest rates than conventional properties because of the various buildings' different conditions (Choi, 2009). This means that real estate investors (developers) and financiers in Ghana are likely to benefit from clear market incentives and are expected to realise high returns on their investments should they venture into the green building business. Validation interviews with some of the respondents revealed the following regarding this driver:

"Green buildings are good for the environment, of course. But they are also good for business. They improve the health and comfort of your employees and customers [Building Contractor].

They increase real estate and rental values, believe it or not, cost less to maintain than traditional buildings. This is true of retrofits as well as new construction. It is also suitable for the Ghanaian economy [Real Estate Developer].

"Because sustainable and green building projects have a reduced lifecycle cost, in the long run, it has the potential of high returns on investment because the building will be able to stand the test of time, affording the investor a lot of time to enjoy the returns. The capital invested could easily be recouped in the shortest time possible as well" [Architect].

An advantage of investing in green buildings is the developers' ability to rent and sell such facilities because of their advantage over conventional facilities. Investors are all about making profits, and if they can make a higher return on their investments and save the environment, it is an excellent opportunity.

Emerging business opportunity (DV 4): This was the second most important driver, with [MS = 4.70] and [SD $=0.621]$. Unlike DV7, this driver showed an insignificant mean difference between the contractors and consultants $[\mathrm{MD}=0.01]$ and the contractors and developers [MD $=0.01]$. The ANOVA result confirmed this result by revealing that these differences were not statistically significant $(\mathrm{p}=0.868>0.05$ ] (see Table 2). From the combined results, the one-sample t-test revealed that this driver is statistically significant as the mean score is greater than the mean value of 3.5 and the $p$-value is less than $0.05(p=0.000<0.05)$. The validation interviews with some professionals concerning this driver revealed the following:

"There is an emerging demand for green products and services in Ghana because of public awareness on the importance of the environment as well as long term operational cost-benefit. This market is yet to be exploited. Real estate developers with innovative concepts on green building projects are likely to attract domestic and international investment and support from the government 
in the form of tax relief, etc. Access to affordable credit facilities is likely because of less risk and high-profit potential" [Cost Engineering Consultant].

This finding aligns with similar emerging economies like India (Jayanti and Gowda, 2014). This finding again corroborates the work of Umar and Khamidi (2012), who revealed that in Egypt and South Africa, investing in green buildings is now seen as an emerging business opportunity, with new doors being opened for investors. The increasing evidence of climate change has increasingly encouraged businesses to play active roles in reducing sustainability burdens and preserve resources for future generations (Jayanti and Gowda, 2014). Since green building development is still in its infancy in Ghana, investing in it can present various opportunities like manufacturing new materials that meet sustainable standards. Investors such as the International Finance Corporation has taken the lead in this business venture by investing in the manufacturing sector to produce quality and affordable materials for sustainable construction (IFC, 2010). Yudelson (2010) argued that several investors were taking advantage of the incentives such as tax grants to diversify their investment into an investment portfolio concerned with sustainable construction to maximise their profits. This is considered an important driver because for financial institutions in Ghana, investing in green buildings can expand their green construction and mortgage finance products to build higher value and lower risk portfolios. Also, for building developers, it will provide them with a clear understanding of the business case for green buildings and how to differentiate themselves in the market to grow their businesses. A real estate developer interviewed for the validation commented as follows:

"A growing number of brilliant and creative designs are emerging from the African continent, and the world is starting to take notice. Future growth in Africa presents a tremendous opportunity to reinvent the way, guidance, and direction of an emerging green building market. With emerging business opportunities coming in, so as it attracts investors and then convincing them by using the opportunity to engage in green building as the other parts of Africa have started investing in green building" [Real Estate Developer].

Promoting ethical investment (DV2): This driver was considered as the third most important driver, with a mean score $[\mathrm{MS}=4.65]$ and a standard deviation $[\mathrm{SD}=0.802]$. For this driver, there existed some difference between the views of the consultants and developers [MD $=0.12]$ and the contractors and the developers $[\mathrm{MD}=0.05]$. However, from the ANOVA result, these differences were not statistically significant $(\mathrm{p}=0.975>0.05]$ (see Table 2$)$. The one-sample t-test for the combined results revealed that this driver promoting ethical investment is statistically significant. The mean score is greater than the mean value of 3.5, and the $p$-value is less than $0.05(p=0.000<0.05)$. This finding agrees with that reported in the literature (Rimmer, 2016; Youssef and Whyte, 2016; Azreen and Shauki, 2012). Ethical investment is a new trend in the finance sector, where certain investments are geared towards projects that are considered only on ethical grounds. It is an open and transparent business practice based on ethical values and respect for employees, communities, and the environment (Azreen and Shauki, 2012). This study showed that, like that reported in Malaysia (Azreen and Shauki, 2012), Norway (Rimmer, 2011), the respondents in Ghana consider the promotion of ethical investment as a key driver for green building project financing.

According to Tseng et al. (2019), ethical or sustainable investments affect sustainable developments by coordinating monetary concerns and long haul environmental, social, and governance criteria while making investment decisions. Over the years, construction industry participants who strived for sustainable developments had firmly focused their attention on environmental considerations. This has led to the development of various tools and methods for assessing green buildings' environmental quality and performance (Lützkendorf and Lorenz, 2005). Despite the many awareness creation mediums available on sustainable construction, sustainable buildings or building projects are not fully requested by most of the market participants (Lützkendorf and Lorenz, 2005). Key among this problem is that there is a lack of mechanisms to align environmental and social issues with economic returns. However, of late, ethical investment has been identified as a key driver in promoting sustainable project financing. Some interviewees suggested the following: 
"Provided the companies that will be investing share the same values, customers might feel the companies are helping in the part of changing the economy for the better. If companies deliver good returns, then you will have the added value or bonus of benefiting financially from the values. As investors back more socially responsible projects and businesses, other companies will look to improve their ethical behaviours to attract funding " [Building contractor].

"Recently, the Bank of Ghana, with support from Ghana Association of Bankers, published Sustainable Banking Principles and Sector Guidance Note to guide the banking sector to realign shareholder profit maximisation to include environmental integrity and climate change issues. This demonstrates the commitment of champions of the banking sector towards green issues. Building projects that do not incorporate the green concept will soon be challenged in assessing credit facilities from banks in Ghana" [Cost engineering consultant].

Conservation of resources (DV 6): As the fourth key driver with an overall mean score of [MS = $4.54]$ and a standard deviation $[\mathrm{SD}=0.588]$, this driver showed some difference between the views of the consultants and developers [MD $=0.09]$, and the contractors and the developers [MD $=0.02]$. However, from the ANOVA result, these differences were not statistically significant $(p=0.997>$ 0.05] (see Table 2). The one-sample t-test for the combined results further revealed that this driver conservation of resources is statistically significant. The mean score is greater than the mean value of 3.5 , and the $p$-value is less than $0.05(p=0.000<0.05)$. Construction of buildings, operations, and deconstruction impacts use $15 \%$ of the world's freshwater resources, $40 \%$ of the world's energy, and produces approximately $30 \%$ of the world's green gas emissions (Reddy, 2016). About $17 \%$ of the world's water sources, $25 \%$ of forestry products, and $40 \%$ of energy sources are consumed by the construction sector (Gültekin et al., 2018). These statistics present clear cases to the construction sector to manage and preserve the natural resources with the utmost care. The respondents considered conservation of resources as an important driver for the implementation of sustainable building project financing. This driver has been extensively reported in other green building-related studies in countries like the USA, UK, and Canada (Darko et al., 2017), Republic of Korea (Lee et al., 2013), and Hong Kong (Lam et al., 2010).

As part of conserving natural resources, sustainable building designs and construction have been encouraged in the built environment. Gültekin and Yavaşbatmaz (2008) indicated that organisations invest in sustainable building design and construction to create a built environment that does not disrupt the ecological balance, minimises the harmful impacts of buildings on the environment, uses resources economically, and provide the necessary conditions for human comfort and health. Following the environmental problems posed by the construction sector, most organisations have resorted to investing in environmentally sustainable design and construction practices to reduce the negative impacts on natural resources. The following are what the interviewees had to say:

"Green building, with its use of renewable energy, recycling, and reduction of pollution and waste involves more responsible, rational, and sustainable use of land, raw materials, energy and water. This, in turn, should lead to a healthier, more comfortable environment and a stronger economy" [Real estate developer].

"Clients need to be educated on the long-term benefits of investing in buildings that pose little or no threat to the environment (the initial investment could be expensive, but the long-term benefits are worth it) to make this driver effective" [Architect].

"They need to be educated on the need to recommend and use building materials and techniques that will not harm the environment, and which will also not compromise on the need to provide them with the needed comfort" [Building contractor].

Mandatory regulations, standards, and policies (DV 8): This is the fifth most important driver and obtained a mean score $[\mathrm{MS}=4.50]$ and a standard deviation $[\mathrm{SD}=0.502]$. For this driver, there were differences between the views of all the three respondent groups (see Table 2). A mean difference of 0.06 was recorded between the contractors and consultants, between the consultants and developers, a 
mean difference of 0.04 was recorded, and between the contractors and the developers, a mean difference of 0.10 was recorded. Despite these mean differences, the ANOVA results revealed that these differences were not statistically significant $[p=0.616>0.05]$. The one-sample t-test for the combined results showed that these mandatory driver regulations, standards, and policies are statistically significant. Its mean score is greater than the mean value of 3.5 , and the $p$-value is less than $0.05(p=0.000<0.05)$. This driver identified corroborates that found in other studies in countries like New Zealand (Azizi et al., 2011), the Republic of Korea (Lee et al., 2013), South Africa (Windapo, 2014), among others.

The most cost-effective way to reduce the use of resources during the life of a building is to incorporate green measures during the design and construction stages. According to Vaughan and Turner (2013), mandatory building codes see that green efforts are considered from the start of the building through to the end. Azizi et al. (2011) indicated that the impact of international pressure on governments worldwide is making them put a premium on formulating legislation that moves the construction industry towards sustainability. In Hong Kong, one of the drivers used to promote financing and participation in sustainable construction projects is implementing regulations that will encourage stakeholders in the construction industry to make environmental changes to their operations. Darko et al. (2018) noted that the construction industry introducing standards as to how construction is done going forward by implementing sustainable construction practices was a way of driving interest in investors investing in the sector, knowing that their projects adhere to standards that conserve the environment. The (validation) interviewees supported the need for this driver and indicated the following:

"Regulations, standards, and policies will provide the legal framework within which construction activities can be carried out. Any activity outside of the framework will be deemed as illegal" [Building Contractor].

"Financial Institutions and private investors would not want to invest or fund any project that is deemed illegal for fear of prosecution and bad corporate image. Most of the buildings that spring up in Ghana are funded by the Government of Ghana. Hence, it is easier for the government to liaise with the necessary stakeholders and institute such regulations" [Cost engineering consultant].

"To get all the institutions and citizens on board the 'sustainable train', it is necessary for the government's Legislation arm to pass a law and get the respective institutions to enforce it. With time, building in sustainable ways will become the norm" [Architect].

"Ghanaian communities should have more options than ever for encouraging greener building and development. Many organisations should develop model codes or rating systems that communities can use to develop green building programs or revise building ordinances" [Real estate developer].

\section{CONCLUSION}

Despite the benefits of green buildings worldwide, private and public developers often find it challenging to fund such projects. A 2019 worldwide sustainability market survey revealed that people have a general perception that sustainability measures increase a given project's cost (IFC, 2019). Though emerging economies have ambiguous targets for green buildings, they seem to have few measures to mandate and incentivise the large-scale adoption of green construction practices. Ghana, an emerging economy, has made efforts to certify a small number of recent building projects using certification tools such as Green Star South Africa and EDGE. Despite this, most green building projects are still at their initial stages. Some scholars have attributed this problem to certain impediments in developing the green building market in Ghana, of which finance is considered key. Though this problem has been identified, most green building-related studies have concentrated on environmental benefits, innovative designs, construction technologies, and project management techniques - to the detriment of financial issues. Among the many studies conducted on green buildings in Ghana, just a few have sought to tackle the financing aspect of such buildings; with the 
latest one conducted to identify the obstacles to green building project financing in Ghana (Agyekum et al., 2020). This therefore left a knowledge gap concerning the factors that could drive stakeholders to finance such buildings, which consequently motivated this study to be undertaken to examine the drivers for green building project financing in Ghana.

A mixed-method approach (both quantitative and qualitative) was used in this study. The design used was exploratory sequential and used qualitative data to augment the study's quantitative outcome. This design involved two stages, i.e., an initial quantitative instrument phase (where eight potential drivers were identified in a critical comparative review of related literature), followed by a qualitative data collection phase. In the quantitative phase, a questionnaire was prepared and administered among contractors, consultants, and developers in the Ghanaian construction industry with knowledge of the green building concept. Data from the quantitative phase was analysed via descriptive and inferential analysis. The data obtained from the questionnaire survey was later validated through ten semistructured interviews with key professionals in the Ghana Green Building Council, who all agreed with the drivers' choice.

The study's findings revealed that although all the eight drivers were significant, five out of the eight were rated as key drivers. The five key drivers identified were 'high return on investment' 'emerging business opportunity', 'ethical investment', 'conservation of resources', and 'mandatory regulations, standards, and policies'. These five key drivers were also consistent with drivers identified in similar studies in the USA, UK, Hong Kong, Republic of Korea, and South Africa. What made these five identified key drivers unique is their association with Ghana's situation. With these findings, stakeholders and industry practitioners can make better-informed decisions regarding the drivers that can enable them to finance green building projects more successfully in Ghana.

The implications for these findings are two-fold. Theoretically, this study has established key drivers important for green building project financing in a typical developing country setting (in this case, Ghana), currently under-reported in the literature. The identification of these drivers advances knowledge within the subject area. More practically, the findings are essential for financial institutions, investors, and developers. For financial institutions, investing in green buildings can expand their green construction and mortgage finance products to build higher value and lower risk portfolios. Investing in green building is considered a good thing, and sound investment returns result from informed investment decisions in line with investors' objectives. For investors, the findings from this study must be able to give them the needed certainty to guide and inform their investment decisions i.e., what to invest in,when, how much and how a scheme being 'green' may influence their rate of return. Also, for building developers, it will give them a clearer understanding of the business case for green buildings and how to differentiate themselves in the market to grow their businesses. Though this study was conducted within Ghana, the findings and implications could also help policymakers, stakeholders, and practitioners in wider Sub-Saharan Africa, especially those with similar industry settings like Ghana.

A key limitation of this study lies in the analytical tool used to analyse the data. Since specific drivers like corporate image and corporate social responsibility are latent and unobserved variables, some indicators would be good to measure them. Again, this study however, did not establish the relationship between some of the key drivers identified. It is therefore recommended that future studies investigate this problem using a robust analytical tool like the Structural Equation Modelling (SEM), to establish the significant relationship between the variables, especially the latent ones. Another significant limitation is this study's inability to collect data from contractors, consultants, and developers in other cities in Ghana, apart from Kumasi and Accra. Also, the views of other key stakeholders like the government, financial institutions, and consumers were not sought. Future studies could collect data from respondents in the remaining cities of Ghana and other key stakeholders to provide additional empirical realities to broaden the understanding of the views of these stakeholders on the factors that drive green building project financing. 


\section{REFERENCES}

Addy, M.N. Adinyira, E., Danku, J.C. and Dadzoe, F. (2020), "Impediments to the development of the green building market in Sub-Saharan Africa: the case of Ghana", Smart and Sustainable Built Environment, DOI 10.1108//SASBE-12-2019-0170.

Agyekum, K., Adinyira, E. and Oppon, J.A. (2021), "Factors limiting the adoption of hemp as an alternative sustainable material for green building delivery in Ghana", International Journal of Building Pathology and Adaptation, available at: https://www.emerald.com/insight/content/doi/10.1108/IJBPA-11-2020-0100, accessed 23 March 2021.

Agyekum, K., Opoku, A., Oppon, A.J. and Opoku, D-G.J. (2020), “Obstacles to green building project financing", International Journal of Construction Management, available at: https://doi.org/10/1080/15623599.2020.1832182, accessed 2 March 2021.

Agyekum, K. Adinyira, E. and Ampratwum, G. (2020), "Factors driving the adoption of green certification of buildings in Ghana", Smart and Sustainable Built Environment, Vol. 9 No. 4, pp. 595-613.

Agyekum, K., Adinyira, E., Baiden, B.K. and Ampratwum, G. (2019), "Barriers to the adoption of green certification of buildings: A thematic analysis of verbatim comments from Built Environment Professionals", Journal of Engineering, Design and Technology, Vol. 17 No. 5, pp. 1035-1055.

Akadiri, P.O., Chinyio, E.A., and Olomolaiye, P.O. (2012), "Design of a sustainable building: A conceptual framework for implementing sustainability in the building sector", Buildings, Vol. 2 No. 2, pp.126-152.

Akotia, J. and Sackey, E. (2018), "Towards the delivery of sustainable regeneration projects' types in the UK: an exploration of the role and level of involvement of key practitioners". International Journal of Construction Management, Vol. 18 No. 5, pp. 375-384.

Ampratwum, G., Agyekum, K., Adinyira, E. and Duah, D. (2019), "A framework for the implementation of green certification of buildings in Ghana", International Journal of Construction Management, available at: https://doi.org/10.1080/15623599.2019.1613207, accessed 3 March 2021.

APEC. (2018). Promoting Innovative Green Financing Mechanisms for Sustainable and Quality Infrastructure Development in the APEC Region (Issue August).

AlSanad, S. (2015), "Awareness, drivers, actions, and barriers of sustainable construction in Kuwait", Procedia engineering, Vol. 118 (2015), pp.969-983.

Andelin, M., Sarasoja, A.L., Ventovuori, T. and Junnila, S. (2015), "Breaking the circle of blame for sustainable buildings-evidence from Nordic countries", Journal of corporate real estate, Vol. 17 No. 1, pp.26-45

Azizi, M.S., Sakina, N., Fassman, E. and Wilkinson, S. (2011), "Risks associated in implementation of green buildings", Auckland, New Zealand: Department of Civil Environmental Engineering.

Azreen Adam, A. and Shauki, E. (2012), "Socially responsible investment in Malaysia: Behavioural framework in evaluating investors' decision-making process", In Procs $11^{\text {th }}$ A-CSEAR Conference -University of Wollongong, Sydney, 2-4 December, 2012, pp. 1-45.

BCA. Singapore: Leading the Way for Green Buildings in the Tropics. 2014. Available online: https://www.bca.gov.sg/greenmark/others/sg_green_buildings_tropics.pdf (accessed on 21 March 2019).

Bhandari, J. (2014), South Africa's green fund, available at:

https://www.greenfinanceplatform.org/sites/default/files/downloads/best-

practices/GGBP\%20Case $\% 20$ Study $\% 20$ Series South\%20Africa Green $\% 20$ Fund.pdf, accessed 3

March 2021. 
Bielenberg, A., Kerlin, M., Oppenheim, J. and Roberts, M. (2016), "Financing change: How to mobilize private-sector financing for sustainable infrastructure", McKinsey Center for Business and Environment.

Bonett, DG and Wright, T.A. (2015), "Cronbach's alpha reliability: Interval estimation, hypothesis testing, and sample size planning”, Journal of Organizational Behavior, Vol. 36 No. 1, pp.3-15.

Botchway, S.Y. (2020), 'Key indicators for assessing sustainability during the construction phase of building projects in Ghana', An MPhil Thesis submitted to the Department of Construction Technology, Kwame Nkrumah University of Science and Technology, Kumasi, Ghana.

Chakravarthi D.P. and Aravindan A. (2019), "A study on financing for sustainable construction projects", International Journal of Recent Technology in Engineering, Vol. 7 No. 6, pp.16917

Chan, A.P.C., Darko, A., Olanipekun, A.O. and Ameyaw, E.E. (2018), "Critical barriers to green building technologies adoption in developing countries: The case of Ghana", Journal of Cleaner Production, Vol. 172 No. 1, pp. 1067-1079.

Chan, E.H., Qian, Q.K. and Lam, P.T. (2009), "The market for green building in developed Asian cities - the perspectives of building designers", Energy Policy, Vol. 37 No. 8, pp.30613070 .

Chen, Y.S. (2008), "The driver of green innovation and green image - green core competence", Journal of Business Ethics, Vol. 81 No. 3, pp. 531-543.

Chen, Y.S., Lai, S.B. and Wen, C.T. (2006), "The influence of green innovation performance on corporate advantage in Taiwan", Journal of Business Ethics, Vol. 67 No. 4, pp. 331-339.

Chmutina, K., Wiersma, B., Goodier, C.I. and Devine-Wright, P. (2014), "Concern or compliance? Drivers of urban decentralised energy initiatives", Sustainable Cities and Societies, Vol. 10 (2014), pp. 122-129.

Choi, C. (2009), "Removing market barriers to green development: principles and action projects to promote widespread adoption of green development practices", Journal of Sustainable Real Estate, Vol. 1 No. 1, pp.107-138.

Crouse, T. and Lowe, P.A. (2018), "Snowball sampling", in: The SAGE Encyclopaedia of Educational Research, Measurement and Evaluation, pp. 1-3, available at: https://dx.doi.org/10.4135/9781506326139, accessed 9 March 2021.

Cui, Y., Geobey, S., Weber, O. and Lin, H. (2018), "The impact of green lending on credit risk in China”, Sustainability, Vol. 10 No. 6, pp 1-16

Dania, A.A. (2017), "Sustainable construction at the firm level: case studies from Nigeria", A Doctoral dissertation submitted to the University of Reading.

Darko, A. (2019), "Adoption of green building technologies in Ghana: Development of a model of green building technologies and issues influencing their adoption", A PhD Thesis submitted to Department of Building and Real Estate, The Hong Kong Polytechnic University, Hong Kong.

Darko, A., Chan, A.P.C., Yang, Y., Shan, M., He, B.-J. and Gou, Z. (2018), "Influences of barriers, drivers and promotion strategies on green building technologies adoption in developing countries: The Ghanaian case", Journal of Cleaner Production, Vol. 200 No. 1, pp. 687-703.

Darko, A., Chan, A.P.C., Owusu-Manu, D.-G. and Ameyaw, E.E. (2017), Drivers for implementing green building technologies: An international survey of experts, Journal of Cleaner Production, Vol. 145 (2017), pp. 386-394.

Darko, A., Chan, A. P. C., Ameyaw, E. E., He, B.-J. and Olanipekun, A. O. (2017), "Examining issues influencing green building technologies adoption: The United States green building experts" perspectives, Energy and Buildings, Vol. 144 No. 6, pp. 320-332.

Day, J. (2019), Green buildings: The epicenter of responsible investing, ESG disclosure requirements 
and financial incentives, available at: http:www.jonesday.com, accessed 4 March 2021.

Della Croce, R., Kaminker, C. and Stewart, F. (2011), "The role of pension funds in financing green growth initiatives", OECD Publishing, Paris.

Diyana, A. N. and Abidin, N. Z. (2013), "Motivation and expectation of developers on green construction: a conceptual view", In Proceedings of World Academy of Science, Engineering and Technology, No. 76, p. 247.

Dwaikat, L.N. and Ali, K.N. (2016), "Green buildings cost premium: A review of empirical evidence", Energy and Buildings, Vol. 110 No. 1, pp. 396-403.

Dwaikat, L. N. and Ali, K. N. (2014), "Green Buildings Actual Life Cycle Cost Control: A Framework for Investigation", 13th Management in Construction Researchers' Association (MiCRA) Annual Conference and General Meeting, 06 November 2014

Enshassi, A. and Mayer, P.E. (2005), "Barriers to the application of sustainable construction concepts in Palestine", In Proceedings of the 2005 World Sustainable Building Conference, Tokyo, Japan, 27-29 September 2005

Eskelson, D., Antal, I., Fidanza, B., Leclercq, M., \& Rosca, A. (2016). GREEN-WIN: Green growth and win-win solutions for sustainable climate action; 642018 RIA.

EY (2015), Green Bonds: A fresh look at financing green projects, EY Publishing. doi: 10.1017/CBO9781107415324.004.

Field, A. (2013), Discovering statistics using IBM SPSS statistic. 4th ed. Los Angeles, CA: Sage.

Fletcher, L.K. (2009), "Green construction costs and benefits: Is national regulation warranted", Natural Resources and Environment, Vol. 24 No. 1 pp.18-24.

Franc, P., Nezhyba, J. and Heydenreich, C. (2006), Taking corporate social responsibility seriously. Environmental Law Service.

Frost, J. (2020), Introduction to statistics: An intuitive guide for analysing data and unlocking discoveries. Statistics by Jim Publishing, USA, pp. 256

Fuerst, F. and McAllister, P. (2011), "Green Noise or Green Value? Measuring the Effects of Environmental Certification on Office Values", Available at: http://immobilierdurable.eu/images/2128 uploads/Fuerst article autoris .pdf., accessed May 2020.

Global Sustainable Investment Alliance. (2019). Global sustainable investment review 2018.

Retrieved from http://www.gsi-alliance.org/wp-content/uploads/2019/06/GSIR_Review2018F.pdf

Green Building Council Australia (2008), The dollars and sense of green buildings 2008;

Green Building Council Australia; Barangaroo, Australia, 2008.

Gültekin, A.B. and Yavaşbatmaz, S. (2008), "Sustainable design of tall buildings", Journal of the Croatian Association of Civil Engineers, Vol. 65 No. 5, pp. 449-461.

Gündoğan, H. (2012), "Motivators and barriers for green building construction market in Turkey", Yayımlanmamış yüksek lisans tezi. Orta Doğu Teknik Üniversitesi, Ankara.

Halper, M. (2015), Green investment bank launches industry-wide led retrofit funding. First Stop,

GKN, Aerospace, available at: http://luxreview.com/article/2015/06/green-investment-bank-launchesindustry-wideled-retrofit-scheme-at-gkn-aerospace, accessed 3 March 2021.

Höhne, N., Khosla, S., Fekete, H. and Gilbert, A. (2012), "Mapping of green finance delivered by IDFC members in 2011, Available at:

http://www.idfc.org/Downloads?Publications/01_green finance mappings/IDFC Green finance Mapping Report 2012 14-06-12, accessed 5 April 2020.

Hupp, E.E.P. (2010), "Refining green building regulations and funding green buildings in order to achieve greenhouse gas reductions", The Urban Lawyer, Vol. 42 No. 3, pp. 639-648.

Hwang, B.-G., Shan, M. and Phua, S.L. (2018), "Safety in green building construction projects in Singapore: Performance, critical issues and improvement solutions". KSCE Journal of Civil Engineering, Vol. 22(2018), pp. 447-458.

Inderst, G., Kaminker, Ch., Stewart, F. (2012), "Defining and Measuring Green Investments: Implications for Institutional Investorse Asset Allocations", OECD Working Papers on 
Finance, Insurance and Private Pensions, No.24, OECD Publishing.

International Finance Corporation, IFC, (2019), "Green buildings: A finance and policy blueprints for emerging markets", Available athttps:// www.ifc.org, accessed 10 May 2020.

International Finance Corporation, IFC, (2018), Climate Investment Opportunities in Cities, available at: https://www.ifc.org/wps/wcm/connect/

topics_ext_content/ifc_external_corporate_site/climate+business/resources/cioc-ifcanalysis, accessed 13 May 2020

International Finance Corporation, IFC, (2017), “Green Buildings Market Intelligence : Ghana Country Profile", Available at: https://www.ifc.org, Accessed 20 Febuary 2019

International Finance Corporation, IFC, (2010), "Green Business Opportunities in Manufacturing, Agribusiness and Services", Available at: https://www.ifc.org, Accessed 18 March 2019

Jayanti, R.K. and Gowda, M.V.R. (2014), "Sustainability dilemas in emerging economies", IIMB Management Review, Vol. 26 (2014), pp. 130-142.

Jeucken, M. (2001), Sustainable finance and banking: The financial sector and the future of the planet. Earthscan Publications Ltd.: London.

Kakkar, AA (2014), "Resource management for green buildings", International Journal of Civil Engineering Research, Vol. 5, pp.443-446.

Kates, R. W., Parris, T. M. and Leiserowitz, A. A. (2005), "What is sustainable development? Goals, indicators, values, and practice", Environment, Vol. 47 No. 3, pp. 8-21.

Kats, G., Menkin, A., Dommu, J., \& Debold, M. (2011). Energy Efficiency Financing-Models and Strategies. In Prepared by Capital E For The Energy Foundation.

Khosla, S. and Singh, S.K. (2014), "Energy efficient buildings", International Journal of Civil Engineering Research, Vol. 5 No. 4, pp.361-366.

Klein, J. and Dawar, N. (2004), "Corporate social responsibility and consumers' attributions and brand evaluations in a product - harm crisis", International Journal of Research in Marketing, Vol. 21 No. 3, pp. 203-217.

Ko, E., Hwang, Y.K. and Kim, E.Y. (2013), "Green marketing' functions in building corporate image in the retail setting", Journal of Business Research, Vol. 66 No. 10, pp. 1709-1715.

Lam, P. T., Chan, E. H., Poon, C., Chau, C. and Chun, K. (2010), "Factors affecting the implementation of green specifications in construction", Journal of environmental management, Vol. 91 No. 3, pp. 654-661.

Lee, S., Lee, B., Kim, J. and Kim, J. (2013), “A financing model to solve financial barriers for implementing green building projects", The Scientific World Journal, 2013.

https://doi.org/10.1155/2013/240394

Lockwood, C. (2008), "The dollars and sense of green retrofits", Washington DC: Deloitte.

Lotfi, M., Yousefi, A. and Jafari, S. (2018),” The effect of emerging green market on green entrepreneurship and sustainable development in knowledge-based companies", Sustainability, Vol. 10 No. 7, pp. 1-18.

Love, P.E., Liu, J., Matthews, J., Sing, C.P. and Smith, J. (2015), "Future proofing PPPs: Life-cycle performance measurement and building information modelling", Automation in Construction, Vol. 56 (2015), pp.26-35.

Low, S. P., Gao, S. and Tay, W. L. (2014), "Comparative study of project management and critical success factors of greening new and existing buildings in Singapore", Structural Survey, Vol. 32 No. 5, pp. 413-433.

Lützkendorf, T. and Lorenz, D. (2005), "Sustainable property investment: valuing sustainable buildings through property performance assessment", Building Research and Information, Vol. 33 No. 3, pp. 212-234.

Manoliadis, O., Tsolas, I. and Nakou, A. (2006), "Sustainable construction and drivers of change in Greece: a Delphi study", Construction Management and Economics, Vol. 24 No. 2, pp.113120.

Masia, T., Kajimo-Shakantu, K. and Opawole, A. (2020), "A case study on the implementation of green building construction in Gauteng Province, South Africa", Management of 
Environmental Quality: An International Journal, Vol. 31 No. 3, pp. 602-623.

Mathews, J.A. (2012), "Green growth strategies-Korean initiatives”, Futures, Vol. 44 No. 8, pp.761769.

Mcwilliams, A. and Siegel, D. (2001), "Corporate Social Responsibility : A Theory of the Firm

Perspective", Academy of Management Review, Vol. 26 No. 1, pp. 117-127.

Meltzer, J.P. (2015), "Financing sustainable infrastructure", Brookings Brief.

Merk, O., Saussier, S., Staropoli, C., Slack, E., Kim, J-H (2012), "Financing Green Urban Infrastructure", OECD Regional Development Working Papers 2012/10, OECD Publishing; http://dc.doi.org/10.1787/5k92p0c6j6r0-en

Michelson, G., Wailes, N., Van Der Laan, S. and Frost, G. (2004), "Ethical investment processes and outcomes", Journal of Business Ethics, Vol. 52 No. 1, pp.1-10

Neyestani, B. (2017), "A review on sustainable building (Green building)", SSRN Electronic Journal, Vol. 6 No. 1, pp. 451-459.

Nguyen, M. (2014), Green Buildings, Corporate Social Responsibility, and Stock Market Performance. A thesis submitted to Portland State University.

OECD (2015), Green Bonds Mobilising the debt capital markets for a low-carbon transition, OECD/IEA Publishing. doi: 10.1016/S0140-6736(09)60318-4.

OECD (2014) 'Environmental Lending in EU Eastern Partnership Countries'. doi: 10.1787/9789264252189-en.

OECD (2012), Financing Climate Change Action. Available at: http://www.oecd.org/env/climatechange/49096643., accessed 12 May 2020

O'Mara, M. and Bates, S. (2012), Why invest in high-performance green buildings. VP high performance green buildings solutions and Shan Bates, LEED AP, Global Segment LeadEducation \& Smart Campus Solutions. White paper.

Opoku, D-G., Ayarkwa, J. and Agyekum, K. (2019), "Barriers to environmental sustainability of construction projects", Smart and Sustainable Built Environment, Vol. 8 No. 4, pp. 292306.

Orlitzky, M., Siegel, D.S. and Waldman, D.A. (2011), "Strategic corporate social responsibility and environmental sustainability", Business \& society, Vol. 50 No. 1, pp.6-27.

Parse, RR (1990), "Parse's research methodology with an illustration of the lived experience of hope", Nursing Science Quarterly, Vol. 3 No. 1, pp. 9-17

Partnership for Action on Green Economy, PAGE, (2015), Green finance study in Ghana: Baseline report, available at: https://www.un-page.org, accessed 10 March 2021.

Patil., N.A. and Boeing, L. (2016), "Public-private partnerships from sustainability perspective- a critical analysis of Indian case", International Journal of Construction Management, Vol. 16 No. 2, pp. 161-174.

Punzi, M.T. (2019). Role of Bank Lending in Financing Green Projects: A Dynamic stochastic general equilibrium approach. ADBI Working Paper, No. 881, Asian Development Bank Institute ( ADBI), Tokyo, available at: https://doi.org/10.1007/978-981-13-0227-5, accessed 9 March 2021.

Ramboll (2019), "Sustainable buildings market study 2019", Available at: https://www.ramboll.com/buildings, accessed 10 May 2020.

Reddy, V.S. (2016), "Sustainable construction: Analysis of its costs and financial benefits", International Journal of Innovative Research in Engineering and Management, Vol. 3 No. 6 , pp. $522-525$.

Rimmer, M. (2016), "Investing in the future: Norway, climate change, and fossil fuel divestment", Atkins (ed.), Environment, Climate Change and International Relations: Tendencies, Assessments and Perspectives, E-International Relations, pp.206-225.

RoGBC (2014), Green Homes \& Mortgages. Date Accessed 30 ${ }^{\text {th }}$ November 2018

Ross, U. (2015), Green bond drivers. London: HSBC.

Salman, M.T.F., Sayegh M.W and Ayoubi, M.A. (2016), "Green Bonds", Available at: http://www.cedro-undp.org, accessed 10 December 2019. 
Shan, M., Hwang, B.G. and Zhu, L. (2017), "A global review of sustainable construction project financing: policies, practices, and research efforts", Sustainability, Vol. 9 No. 12, p.2347.

Sinha, R. (2009), "Green building: a step towards sustainable architecture", Journal of Infrastructure, Vol. 7 No. 2, pp. 91-102.

Soundarrajan, P. and Vivek, N. (2016), "Green finance for sustainable green economic growth in India", Agricultural Economics, Vol. 62 No. 1, pp.35-44.

Suhr, D. (2006), "The basics of structural equation modelling", University of North Colorado, available at: https://www.lexjansen.com/wuss/2006/tutorials/TUT-Suhr.pdf, accessed 2 March 2021.

Sullivan, R. and Gouldson, A. (2017), "The Governance of Corporate Responses to Climate Change: An International Comparison", Business Strategy and the Environment, Vol. 26 No. 4, pp. 413-425.

The Guardian (2012), The role of private sector in sustainable development, available at:

https://www.theguardian.com/sustainable-business/un-sustainable-development-private-sector, accessed 9 March 2021

Thornley, B., Wood, D., Grace, K. and Sullivant, S. (2011), "Impact Investing: A framework for policy design and analysis", InSight at Pacific Community Ventures \& The Initiative for Responsible Investment at Harvard University

Tobias, L. and Malachite, L. (2017), Toward sustainable financing and Strong markets for green buildings: US Green Building finance review, available at:

http://www3.cec.org/islandora/en/item/2328-paper-2b-toward-sustainable-financing-and-strongmarkets-green-building-en.pdf, accessed 3 March 2021.

Tobias, L. and Llc, M. (2007). 'Paper 2b: "Toward Sustainable Financing and Strong Markets for Green Building: US Green Building Finance Review Leanne Tobias Malachite LLC", Energy, (May), pp. 19-20.

Tseng, M-L., Tan, P.A., Jeng, S-Y., Lin, C-W. R., Negash, Y.T. and Darsono, SNAC (2019), "Sustainable investment: Interrelated among corporate governance, economic performance and market risks using investor preference approach", Sustainability, Vol. 11(2019), pp. 115.

Turner (2010), “Green building market brometer", Available at: http://www.turnerconstruction.com/greenbuildings, accessed 12 May 2020.

Umar, U.A. and Khamidi, M.F. (2012), "Green building for African countries: Opportunities, approaches and challenges, in: $11^{\text {th }}$ Annual Symposium on Sustainability Science and Management, Malaysia, pp. 1-6.

UNEP (2016), Financing sustainable development: Moving from momentum to transformation in a time of turmoil. United Nations Environment Programme Finance Initiative/ Inquiry into the Design of a Sustainable Financial System.

UN Habitat (2018), Sustainable building finance: A practical guide to project financing in East Africa, available at: www.unhabitat.org, accessed 2 March 2021.

Vardhan, H. (2017), "Green Good Deeds", Available at https://www.drharshvardhan.com, accessed 10 April 2020.

Vaughan, E. and Turner, J. (2013), The value and impact of building codes, available at: https://www.eesi.org/papers/view/the-value-and-impact-of-building-codes, accessed 10 March 2021.

Verma, A. (2019), Green buildings to offer $\$ 24.7$ trillion investment opportunity in emerging markets, available at: https://www.iamrenew.com/sustainability/green-buildings-24-7-trillion-investmentopportunity-emerging-markets/, accessed 10 March 2021.

Weerasinghe, A.S. and Ramachandra, T. (2018), "Economic sustainability of green buildings: a comparative analysis of green vs non-green", Built Environment Project and Asset Management, Vol. 8 No. 5, pp.528-543. 
World Green Building Council, WGBC, (2013), "A Review of the Costs and Benefits for Developers Investors and Occupants", Available

at:http://www.worldgbc.org/sites/default/files/Business_Case_For_Green_Building_Report, accessed 15 May 2020

Windapo, A. O. (2014), "Examination of green building drivers in the South African construction industry: economics versus ecology", Sustainability, Vol. 6 No. 9, pp. 6088-6106

Wisdom, J. and Creswell, J.W. (2013), "Integrating quantitative and qualitative data collection and analysis while studying patient-centred medical home models", Rockville, MD: Agency for Healthcare Research and Quality. AHRQ Publication No. 13-0028-EF.

World Green Building Council, WGBC, (2013), "A Review of the Costs and Benefits for Developers Investors and Occupants", Available at:http://www.worldgbc.org/sites/default/files/Business_Case_For_Green_Building_Report, accessed 15 May 2020

World Investment Report (2014), Basic infrastructure, food security, climate change mitigation and adaptation, health and education, available at https://www.un.org/pga/72/wpcontent/uploads/sites/51/2018/05/Financing-for-SDGs-29-May.pdf, accessed 2 March 2021.

Yamaguchi, R. and Managi, S. (2017), "New Financing for Sustainable Development: The Case for

NNP- or Inclusive Wealth-Linked Bonds", Journal of Environment and Development, Vol. 26 No. 2, pp. 214-239.

Yin, R.K. (2014), Case Study Research: Design and Methods, $5^{\text {th }}$ ed.,Sage,Thousand Oaks,CA.

Youssef, S. and Whyte, D. (2016), "Ethical investment: What it is and how it works (or doesnt't)". Available at: https://www.researchgate.net/publication/306066646\%0AEthical, accessed 13 May 2020

Yudelson, J. (2010), The green building revolution. Island Press.

Zhan, C. and de Jong, M. (2018), 'Financing eco cities and low carbon cities: The case of Shenzhen International Low Carbon City', Journal of Cleaner Production, Vol. 180 (2018), pp. 116125.

Zhang, X., Shen, L. and Wu, Y. (2011), "Green strategy for gaining competitive advantage in housing development : a China study”, Journal of Cleaner Production , 19 (2-3), pp. 157-167. 


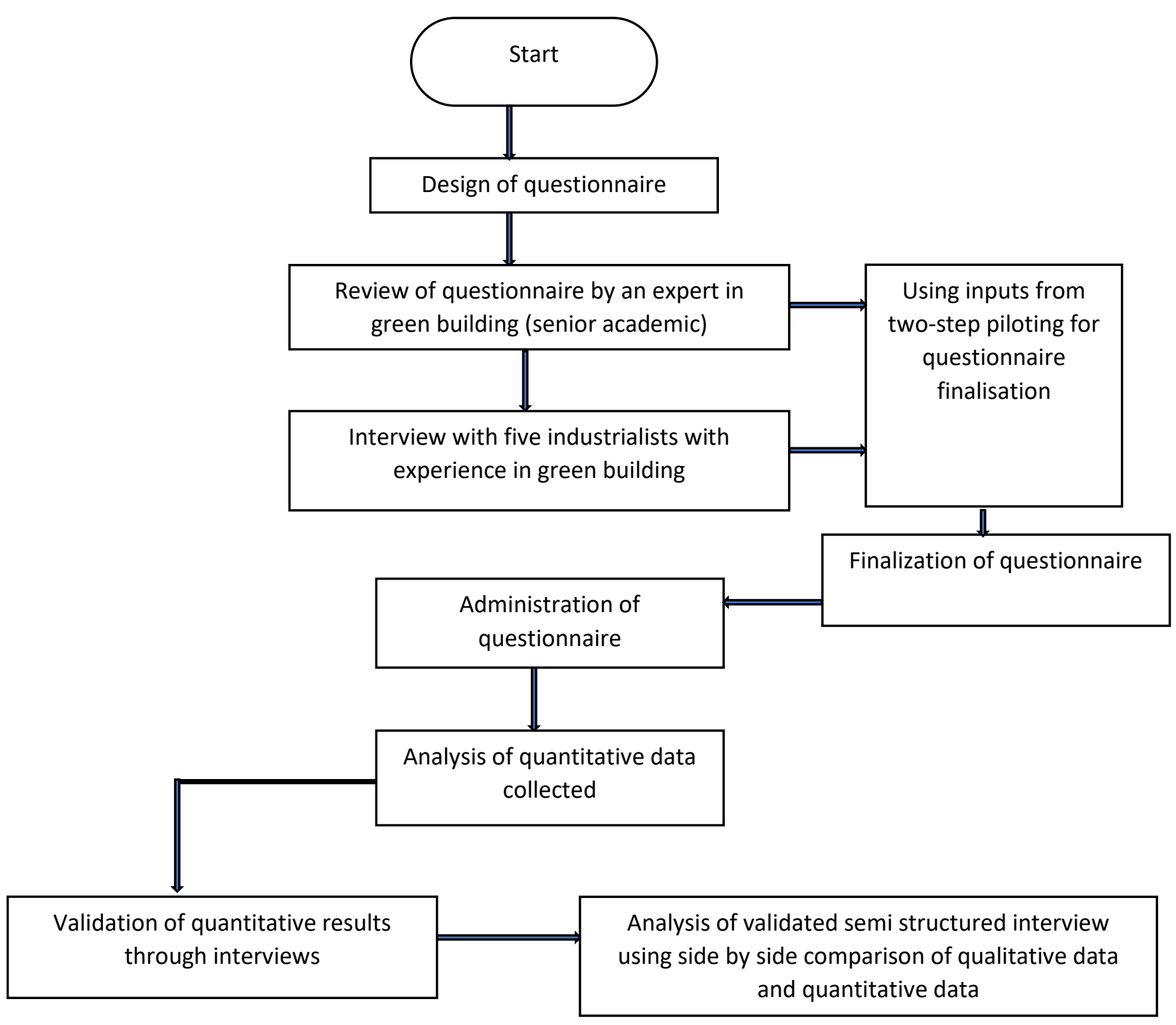

Figure 1: Flowchart showing the methodology used in the study 